\title{
Marta Kołodziej-Hajdo
}

AGH w Krakowie

e-mail: mkolodz1@zarz.agh.edu.pl

\section{SKUTECZNOŚĆC WDRAŻANIA \\ STANDARDÓW KONTROLI ZARZĄDCZEJ \\ W JEDNOSTCE SAMORZĄDU TERYTORIALNEGO}

\section{EFFECTIVENESS OF IMPLEMENTING \\ OF THE STANDARDS OF MANAGEMENT CONTROL IN THE LOCAL GOVERNMENT UNIT}

DOI: $10.15611 /$ pn.2018.514.16

JEL Classification: H10, M10

Streszczenie: Od stycznia 2010 r. jednostki sektora finansów publicznych, w tym jednostki samorządu terytorialnego, zostały zobowiązane do opracowania i wdrożenia procedur systemu kontroli zarządczej. Celem artykułu jest ocena funkcjonowania kontroli zarządczej w wybranej jednostce samorządu terytorialnego w odniesieniu do standardów tej kontroli oraz identyfikacja obszarów wymagających działań korygujących bądź naprawczych. Założony cel został zrealizowany na podstawie wyników uzyskanych podczas badania kwestionariuszowego oraz analizy literatury, aktów prawnych i dokumentów wewnętrznych urzędu miasta. Efektem jest identyfikacja stanu funkcjonowania kontroli zarządczej w jst z punktu widzenia skuteczności i efektywności jej wdrożenia. Pozwoliło to sformułować opinię na temat jakości funkcjonowania kontroli zarządczej w badanej jednostce samorządu terytorialnego.

Słowa kluczowe: finanse publiczne, kontrola zarządcza, samoocena kontroli zarządczej.

Summary: The aim of the article is the assessment of functioning of management control in a selected local government unit in relation to the standards of this control and to identify areas requiring corrective actions. The assumed goal was implemented based on the results obtained during the questionnaire research and analysis of literature, legal acts and internal documents of the City Hall. The result is the identification of the status of the management control in the local government units from the point of view of the effectiveness and efficiency of its implementation. This allowed to formulate an opinion on the quality of the functioning of management control in the local government unit under review.

Keywords: public finance, management control, self-assessment of management control. 


\section{Wstęp}

Zarządzanie każdą organizacją należy rozpatrywać z punktu widzenia wyboru i poszukiwania optymalnych rozwiązań, które pozwolą na osiągnięcie założonych celów i zadań, jednocześnie uwzględniając procedury i zasady postępowania. Jest to rodzaj interakcji między elementami systemu zarządzania - projektowaniem, organizowaniem, wdrażaniem, monitorowaniem i oceną - a osiągniętym celem. W działaniu tym nie można zapominać o podstawowych zasadach takich jak: przestrzeganie prawa, skuteczność, efektywność, oszczędność i terminowość.

Ustawa o finansach publicznych [Ustawa z 27 sierpnia 2009, art. 68, ust. 1] do działalności jednostek sektora finansów publicznych wprowadziła nowy element w obszarze ich funkcjonowania, a mianowicie instytucję kontroli zarządczej. Modyfikuje ona filozofię działania tych jednostek, gdyż poza ujęciem pieniężno-materialnym obejmuje także inne obszary działania: organizacyjne, informacyjne, prawne, proceduralne [Jastrzębska 2012].

Celem artykułu jest ocena wdrożenia systemu kontroli zarządczej w wybranej jednostce samorządu terytorialnego i na tej podstawie identyfikacja elementów wymagających usprawnień bądź działań naprawczych. W badaniu, obejmującym lata 2015 i 2017, obok analizy funkcjonujących rozwiązań wykorzystano kwestionariusz samooceny kontroli zarządczej.

\section{Kontrola zarządcza - pojęcie}

Na podstawie art. 68, ust. 2 ustawy o finansach publicznych [Ustawa z 27 sierpnia 2009] kontrola zarządcza jest wdrażana w jednostce sektora finansów publicznych, aby zapewnić zgodność jej działalności z obowiązującymi przepisami prawa, wewnętrznymi procedurami i regulaminami. Ma to być skuteczne, efektywne i terminowe. Wdrożenie systemu kontroli zarządczej ma także zapewnić wiarygodność sprawozdań, ochronę zasobów, promowanie i przestrzeganie zasad etycznego postępowania, a ponadto efektywność i skuteczność przepływu informacji oraz zarządzania ryzykiem w tych podmiotach. Kontrola zarządcza swym zakresem objęła wszystkie jednostki sektora finansów publicznych, także jednostki samorządu. W dalszej części ustawa o finansach publicznych wskazuje, że zapewnienie funkcjonowania adekwatnej, skutecznej i efektywnej kontroli zarządczej należy bezpośrednio do obowiązków wójta, burmistrza, prezydenta miasta, przewodniczącego zarządu jst.

W literaturze przedmiotu wyróżniane są dwa ideowe fundamenty instytucji kontroli zarządczej. Pierwszy jest wyrazem realizacji zapoczątkowanego w latach 80 . XX w. nurtu rozważań teoretycznych oraz badań empirycznych określonych przez Hooda [1991] jako „nowe zarządzanie publiczne”. Podkreśla to również A. Szpor, który stwierdza, że ideą przenikającą całą ustawę o finansach publicznych jest new public management [Szpor 2011]. Podobne stanowisko prezentuje C. Kosikowski. 
Zwraca on uwagę, że wzrost znaczenia kontroli zarządczej łączy się z menedżerskim podejściem do finansów publicznych, zwłaszcza pod względem zachowania dostatecznej efektywności wydatkowania środków publicznych [Kosikowski 2009]. Drugim fundamentem ideowym tej instytucji jest model kontroli wewnętrznej COSO [Szpor 2011] $]^{1}$. Według tej koncepcji nie jest praktycznie możliwe bądź opłacalne posiadanie stuprocentowej pewności, że wszystkie działania jednostki były w przyjętym okresie skuteczne, efektywne, oszczędne, wykonane w terminie oraz zgodne z literą prawa.

Celem kontroli zarządczej jest usprawnienie kierowania jednostką sektora finansów publicznych na wzór sektora prywatnego. Kierowanie i planowanie oparte jest na modelu zarządczym z uwzględnieniem aspektów zarządzania ryzykiem działalności [Winiarska, Postuła 2012]. Oznacza to, że kontrola zarządcza funkcjonuje jako proces złożony z następujących elementów [Kołodziej-Hajdo 2016]:

1. Planowania - katalog zadań ukierunkowanych na osiągnięcie konkretnych rezultatów.

2. Programowania - wyznaczenie ścieżki działania, która ma doprowadzić do wykonania zadań i osiągnięcia celów.

3. Sprawdzania efektów - w jakim stopniu osiągnięto rezultaty ujęte $\mathrm{w}$ fazie planowania.

4. Analizy odstępstw - wychwycenie rozbieżności pomiędzy założonym celem i rezultatem.

5. Wdrożenia działań korekcyjnych mających optymalizować działania w kierunku założonych celów.

Kontrola zarządcza ma gwarantować efektywne gospodarowanie środkami publicznymi przy wypełnianiu zaplanowanych zadań. Musi zostać przeprowadzona zgodnie ze standardami określonymi w załączniku do komunikatu nr 23 Ministra Finansów z 16 grudnia 2009 r. Zawarte tam standardy nie są źródłem powszechnie obowiązującego prawa. Stanowią jednak zbiór wytycznych wskazujących kierownikowi jednostki ogólne założenia systemu kontroli zarządczej. Organizacja kontroli zarządczej powinna uwzględniać [Sołtyk 2010]:

- specyfikę jednostek sektora finansów publicznych,

- wielkość środków publicznych przydzielonych jednostce,

- projekty finansowane lub współfinansowane ze środków europejskich,

- strukturę organizacyjną jednostki,

- liczbę zatrudnionych pracowników.

Pamiętać także należy, że za niewypełnienie bądź niewłaściwą realizację obowiązków w zakresie kontroli zarządczej [Ustawa z 17 grudnia 2004, art. 18c, ust. 1] można ponieść odpowiedzialność za naruszenie dyscypliny finansów publicznych.

1 Committee of Sponsoring Organizations of the Treadway Commission (Komisja Organizacji Sponsorujących Komisję Treadwaya) była znana pod nazwą COSO. Celem jej było ujednolicenie pojęć w zakresie kontroli wewnętrznej. 


\section{Istota samooceny w kontroli zarządczej}

Piąta grupa standardów kontroli zarządczej „Monitorowanie i ocena” wskazuje na obowiązek monitorowania skuteczności poszczególnych elementów systemu kontroli zarządczej w celu rozwiązywania zidentyfikowanych problemów (standard 19). Ponadto nakłada obowiązek przeprowadzenia co najmniej raz w roku samooceny systemu kontroli zarządczej przez osoby zarządzające oraz pracowników jednostki (standard 20). Jest to ważny element weryfikacji poprawności działania wdrożonego systemu kontroli zarządczej, identyfikujący również obszary, które należy usprawnić.

Samoocena jako forma oceny funkcjonowania systemu kontroli zarządczej ma na celu uzyskanie informacji na temat aktualnej sytuacji jednostki oraz ocenę poziomu realizacji przez nią wymagań wskazanych w standardach. Powinno to mieć miejsce poprzez bieżący przegląd operacji bądź oceny okresowe. Celem samooceny jest [Kumpiałowska (red.) 2011]:

- sprawdzenie jednostki w odniesieniu do pewnych wymogów,

- doskonalenie procesów zachodzących w jednostce,

- wdrażanie nowych standardów funkcjonowania jednostki.

Samoocena jest procesem, który może mieć istotne znaczenie w odniesieniu do tych jednostek, które nie posiadają innych instrumentów oceny kontroli zarządczej (np. audytu wewnętrznego). Wyniki otrzymane podczas samooceny stanowią źródło informacji, które mogą zostać wykorzystane do sporządzenia raportu.

Kierownik jednostki [Ustawa z 27 sierpnia 2009, art. 70, ust. 4] zobowiązany jest do sporządzenia oświadczenia o stanie kontroli zarządczej za poprzedni rok. Oświadczenie o stanie kontroli zarządczej przygotowywane jest zgodnie z rozporządzeniem Ministra Finansów z 2 grudnia 2010 r. Istotą tego dokumentu jest systematyczna ocena stanu kontroli zarządczej oraz jej usprawnianie. W oświadczeniu kierownik jednostki stwierdza, czy kontrola zarządcza osiąga cele określone w ustawie [Ustawa z 27 sierpnia 2009, art. 68 ust. 2]. W sytuacji gdy kontrola zarządcza nie zapewniła łączenia wszystkich jej elementów, kierownik jednostki w oświadczeniu powinien wskazać zastrzeżenia dotyczące funkcjonowania kontroli zarządczej, jak również przedstawić działania, które zostaną podjęte w celu poprawy jej funkcjonowania.

Samoocena systemu kontroli zarządczej może być przeprowadzona za pomocą: - specjalistycznych warsztatów, prowadzonych na zasadach uporządkowanej dyskusji dotyczącej ważnych zagadnień dla organizacji;

- ankiety skierowanej do wszystkich pracowników lub reprezentatywnej grupy wyższego i niższego szczebla².

Biorąc pod uwagę cel sporządzania samooceny kontroli zarządczej, przy jej przygotowaniu i przeprowadzaniu należy uwzględnić szczegółowe wytyczne w za-

2 Szerzej w: [Kontrola zarządcza w jednostkach samorzadu terytorialnego 2011, s. 6-7]. 
kresie samooceny kontroli zarządczej dla jednostek sektora finansów publicznych ${ }^{3}$, które zostały przedstawione przez ministra finansów. Według nich samoocena kontroli zarządczej powinna być jednym z narzędzi stosowanych $\mathrm{w}$ ramach monitorowania kontroli zarządczej ujętym w ramy odrębnego procesu oraz odpowiednio udokumentowanym.

\section{Założenia metodyczne badania}

Samoocena jest ważnym narzędziem weryfikacji systemu kontroli zarządczej w jednostce sektora finansów publicznych.

Badanie samooceny kontroli zarządczej w urzędzie miasta przeprowadzono przy użyciu ankiet dla lat 2015 i 2017, a ich wyniki poddano analizie. Sprawowanie kontroli zarządczej w omawianej jednostce reguluje zarządzenie burmistrza w sprawie regulaminu kontroli zarządczej. Ponadto co roku opracowywany jest dokument „Opis realizacji standardów kontroli zarządczej”, w którym szczegółowo omawiane są mechanizmy kontroli wraz z procedurą ich realizacji. Jako główne cele samooceny w analizowanej jednostce wskazano:

- pozyskanie informacji o funkcjonowaniu kontroli zarządczej na potrzeby podpisania oświadczenia o stanie kontroli zarządczej;

- doskonalenie systemu kontroli zarządczej, w tym zarządzania ryzykiem;

- lepszą współpracę i komunikację między kierownictwem jednostki i pracownikami;

- zidentyfikowanie obszarów niedoskonałości i słabości systemu kontroli zarządczej w urzędzie.

Samoocena w badanej jednostce objęła kompleksowo całą działalność, czyli badanie przeprowadzono w odniesieniu do pięciu elementów kontroli zarządczej. Kwestionariusz ankiety w latach 2015 i 2017 wypełniło 22 pracowników (ok. 95\% załogi), odpowiadając na 31 pytań zamkniętych. W zależności od ocenianego obszaru liczba pytań była zmienna:

1) środowisko wewnętrzne - 10 pytań,

2) cele i zarządzanie ryzykiem - 6 pytań,

3) mechanizmy kontroli -7 pytań,

4) informacja i komunikacja - 7 pytań,

5) monitorowanie i ocena -1 pytanie.

Ocena poziomu efektywności i skuteczności kontroli zarządczej w badanej jednostce opierała się głównie na analizie odpowiedzi twierdzących. Kwantyfikację wprowadzono według trójstopniowej skali:

- ocena 80-100\% - bardzo dobra; minimalna liczba zakłóceń, co oznacza bardzo dobre wdrożenie w danym obszarze systemu kontroli zarządczej; wymagane niewielkie korekty;

3 Szerzej w: [Komunikat nr 3 Ministra Finansów z 16 lutego 2011]. 
- ocena 50-79\% - dostateczne i dobre realizowanie standardów kontroli zarządczej; zastrzeżenia wymagają podjęcia działań usprawniających bądź korygujących;

- ocena 0-49\% - nieprzestrzeganie standardów kontroli zarządczej, liczne nieprawidłowości; wskazane obszary wymagają natychmiastowego wdrożenia działań korygujących i naprawczych; system kontroli zarządczej nie jest efektywny i skuteczny.

\section{Wyniki}

Oceny funkcjonowania systemu kontroli zarządczej w analizowanym urzędzie miasta dokonano według standardów kontroli zarządczej określonych w Komunikacie nr 23 Ministra Finansów. Poniżej (rys. 1) przedstawiono syntetyczne, porównawcze wyniki samooceny za dwa badane okresy.

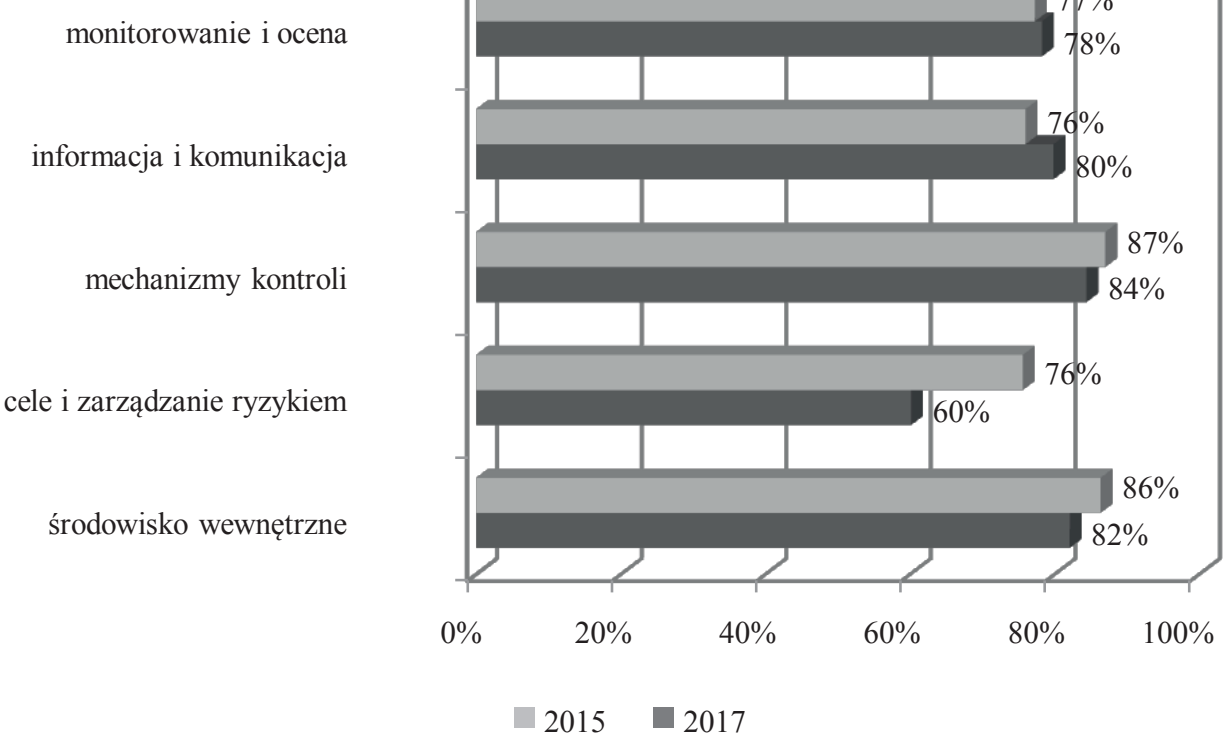

Rys. 1. Syntetyczne ujęcie wyników samokontroli w urzędzie miasta dla lat 2015 i 2017

Źródło: opracowanie własne.

Porównując wyniki samooceny za analizowane lata dla trzech elementów kontroli zarządczej, można zauważyć spadek pozytywnych odpowiedzi w 2017 r. w porównaniu z 2015. W przypadku dwóch elementów: mechanizmy kontroli i środowisko wewnętrzne spadek ten nie przekroczył $4 \%$. Istotne obniżenie, bo o 
$16 \%$, miało miejsce w przypadku elementu cele i zarządzanie ryzykiem. Natomiast w elementach informacja i komunikacja oraz monitorowanie i ocena liczba pozytywnych odpowiedzi w 2017 r. była wyższa niż dwa lata wcześniej. Element cele i zarządzanie ryzykiem, w ocenie pracowników, występuje jako najsłabszy punkt systemu kontroli zarządczej w jednostce. Niepokojące jest jednak znaczne pogorszenie w tym obszarze.

Pozytywnym aspektem jest wzrost pozytywnych odpowiedzi w kluczowych elementach kontroli zarządczej. W wyniku badania należy stwierdzić, że w 2015 r. dwa elementy, a w 2017 r. trzy elementy kontroli zarządczej uzyskały w odpowiedziach pozytywnych (odpowiedzi „TAK”) ocenę $80 \%$ i wyższą. Najsilniejszym zidentyfikowanym obszarem w 2017 r. był element mechanizmy kontroli. W tabeli 1 wskazano rozkład odpowiedzi na zadane pytanie według przyjętej skali ocen.

Tabela 1. Rozłożenie pytań w trójstopniowej skali ocen

\begin{tabular}{|c|l|c|c|c|c|c|c|}
\hline \multirow{2}{*}{ Lp. } & Standard/liczba odpo- & \multicolumn{3}{|c|}{2015} & \multicolumn{3}{|c|}{2017} \\
\cline { 3 - 7 } & wiedzi pozytywnych & $0-49 \%$ & $50-79 \%$ & $80-100 \%$ & $0-49 \%$ & $50-79 \%$ & $80-100 \%$ \\
\hline 1 & $\begin{array}{l}\text { Środowisko } \\
\text { wewnętrzne }\end{array}$ & 1 & 1 & 8 & 0 & 4 & 6 \\
\hline 2 & $\begin{array}{l}\text { Cele i zarządzanie } \\
\text { ryzykiem }\end{array}$ & 0 & 4 & 2 & 1 & 4 & 1 \\
\hline 3 & Mechanizmy kontroli & 0 & 2 & 5 & 0 & 2 & 5 \\
\hline 4 & $\begin{array}{l}\text { Informacja } \\
\text { i komunikacja }\end{array}$ & 1 & 3 & 3 & 0 & 4 & 3 \\
\hline 5 & Monitorowanie i ocena & 0 & 1 & 0 & 0 & 1 & 0 \\
\hline 6 & Razem & 2 & 11 & 18 & 1 & 14 & 16 \\
\hline
\end{tabular}

Źródło: opracowanie własne.

Analizując dane z tabeli 1 bardziej szczegółowo, w ujęciu poszczególnych elementów, można wskazać obszary, które wymagają głębszej analizy, a w dalszej kolejności podjęcia działań naprawczych czy korygujących.

\section{Środowisko wewnetrzne}

W 2015 r. w tym elemencie 59\% respondentów wskazało, że nie uczestniczy w szkoleniach podwyższających kompetencje i umiejętności, dwa lata później sytuacja się poprawiła - wskaźnik spadł do 50\%. Przy czym w 2017 r. wzrósł odsetek osób (z $18 \%$ do $27 \%$ ), które twierdziły, że udział w szkoleniach był niewystarczający, aby skutecznie realizować powierzone im zadania. $27 \%$ respondentów stwierdza, że nie są informowani o wynikach okresowej oceny wykonywanej pracy, choć dwa lata wcześniej nikt nie zaznaczył odpowiedzi „NIE”. Przeważająca większość ankietowanych pracowników (95\%) uważa, że w jednostce funkcjonują zasady etycznego postępowania potwierdzone kodeksem etyki. Podobny odsetek deklaruje, że wie, jak należy się zachować, gdy w jednostce naruszone zostają zasady etyczne. 


\section{Cele i zarzadzanie ryzykiem}

Aż 59\% respondentów w 2017 r. uważa, że nie podano sposobu pomiaru celów do osiągnięcia lub zadań do realizacji w danym roku. Pozytywnie zostały ocenione kwestie dotyczące zarządzania ryzykiem, choć wielu respondentów (38\%) wskazuje braki w tym zakresie. Większość badanych (53\%) stwierdza, że w wydziałach podejmowane są działania ograniczające zidentyfikowane rodzaje ryzyka. Najwyżej (100\% pozytywnych odpowiedzi) oceniono znajomość celów jednostki.

\section{Mechanizmy kontroli}

W latach 2015 i 2017 był to najlepiej funkcjonujący w urzędzie miasta element kontroli zarządczej. Zdecydowana większość respondentów potwierdza bieżący dostęp do procedur i instrukcji obowiązujących w jednostce oraz deklaruje prowadzenie nadzoru ze strony przełożonych, co przekłada się na skuteczną realizację zadań (w 2017 r. odpowiednio $86 \%$ i 95\%).

Najsłabszym ogniwem był nadzór ze strony przełożonych (32\% negatywnych odpowiedzi), natomiast $27 \%$ badanych uważa, że dokumentacja zewnętrzna i wewnętrzna są niewłaściwie przechowywane i chronione przed dostępem osób nieupoważnionych.

\section{Informacja i komunikacja}

Element ten w 2017 r. znacznie się poprawił. Najgorzej respondenci ocenili komunikację z przełożonymi, $36 \%$ uważa, że nie jest ona dobra. Natomiast $64 \%$ pozytywnie ocenia przepływ informacji pomiędzy komórkami organizacyjnymi w jednostce, $95 \%$ ankietowanych deklaruje pełny dostęp do wszystkich informacji i danych niezbędnych do realizacji powierzonych zadań, natomiast $73 \%$ wskazuje, że wymiana informacji ma wpływ na osiąganie celów i realizację zadań. Najlepiej oceniony został system wymiany informacji z podmiotami zewnętrznymi - $95 \%$ ankietowanych uważa go za efektywny.

\section{Monitorowanie i ocena}

Respondenci uważają, że system przeprowadzania monitorowania i oceny jest prawidłowy. Myśli tak 78\% badanych.

Wyniki badania pozwoliły zidentyfikować obszary, które wymagają działań korygujących lub naprawczych. Wśród zasadniczych problemów, na które zwrócili uwagę respondenci, są niewystarczające szkolenia, które pozwoliłyby skutecznie realizować zadania i obowiązki. Również działania w obszarze zarządzania ryzykiem nie są wystarczające, a wręcz pogorszyły się w ciągu dwóch analizowanych lat. Należy zatem stwierdzić, że w analizowanym urzędzie miasta badania spowodowały pozytywne zmiany w odbiorze przez pracowników systemu kontroli zarządczej. 


\section{Zakończenie}

Kontrola zarządcza obejmuje procedury i reguły wdrażane na potrzeby wewnętrzne jednostki. Jednak jej oddziaływanie jest znacznie szersze, bo obejmuje daną społeczność lokalną, a z drugiej strony wpływa na wzrost wiarygodności jednostki. Odpowiedzialność za skuteczne wdrażanie kontroli zarządczej spoczywa na kierowniku jednostki. Jego zadaniem jest, aby procedury i reguły przyjęte przez podmiot skutkowały realizacją celów kontroli zarządczej wskazanych przez ustawodawcę.

Obserwacja kilkuletniego okresu wdrażania systemu kontroli zarządczej w polskich jst pozwala na wnioskowanie, że staje się on skutecznym narzędziem efektywnego zarządzania [Ministerstwo Finansów 2016]. Jedną z podstawowych form oceny kontroli zarządczej jest samoocena dokonywana przez kierownictwo jednostki. Przeprowadzone w urzędzie miasta badania pozwoliły stwierdzić, że poszczególne elementy kontroli zarządczej funkcjonują zgodnie z prawem, terminowo, są skuteczne i efektywne.

Wśród mocnych stron tego systemu w analizowanej jednostce należy wymienić:

- podniesienie skuteczności mechanizmów w obszarze funkcjonowania kontroli operacji gospodarczych i finansowych;

- znajomość misji jednostki, co pozwala na stwierdzenie, że jest ona w tym podmiocie realizowana;

- dobrze funkcjonująca wymiana informacji z podmiotami zewnętrznymi, dzięki znajomości procedur i obowiązków w tym zakresie;

- etyczne zachowania pracowników, zaufanie, delegowanie uprawnień, co istotnie wpływa na odpowiednią jakość pracy.

Do słabych stron tego systemu należą:

- niewielki odsetek osób uczestniczących w szkoleniach bądź udział w szkoleniach, które w znikomym stopniu wpływają na podniesienie skuteczności realizowania powierzonych zadań;

- niewystarczający poziom zarządzania ryzykiem, odzwierciedlony m.in. brakiem kwantyfikacji celów działania poszczególnych komórek organizacyjnych, niskim poziomem identyfikacji zagrożeń i ryzyk;

- $\quad$ słaby przepływ informacji wewnętrznej między kierownictwem a podwładnymi oraz pomiędzy poszczególnymi jednostkami organizacyjnymi;

- niewłaściwie przechowywana i chroniona przed dostępem osób nieupoważnionych dokumentacja zewnętrzna i wewnętrzna.

Badania dowiodły, że w badanym okresie nastąpiła poprawa funkcjonowania poszczególnych elementów kontroli zarządczej, co wskazuje, że jest ona potrzebna jako narzędzie efektywnego zarządzania. Wciąż jednak występują problemy i ograniczenia, które wymagają dalszych działań naprawczych bądź korygujących. 


\section{Literatura}

Hood Ch., 1991, A Public Management for all Seasons?, Public Administration, no 1 (69).

Jastrzębska M., 2012, Finanse jednostek samorzadu terytorialnego, LEX Wolters Kluwer, Warszawa.

Kołodziej-Hajdo M., 2016, Kontrola zarzadcza w jednostkach administracji publicznej-aspekty praktyczne, [w:] P. Bednarek, R. Kowalak, M. Kowalewski (red.), Wyzwania w zarzadzaniu kosztami i dokonaniami, Wydawnictwo Uniwersytetu Ekonomicznego, Wrocław.

Komunikat nr 3 Ministra Finansów z 16 lutego 2011 r. w sprawie szczegółowych wytycznych w zakresie samooceny kontroli zarządczej dla jednostek sektora finansów publicznych, Dz.Urz. MF 2011, nr 2, poz. 11 .

Komunikat nr 23 Ministra Finansów z 16 grudnia 2009 r. w sprawie standardów kontroli zarządczej dla sektora finansów publicznych, Dz.Urz. MF 2009, nr 15, poz. 84.

Kontrola zarzadcza w jednostkach samorzadu terytorialnego, 2011, Departament Audytu Sektora Finansów Publicznych, Biuletyn nr 1, Warszawa, grudzień, s. 6-7.

Kosikowski C., 2009, Reforma finansów w Polsce w świetle nowej ustawy o finansach publicznych, Państwo i Prawo, nr 12, s. 5.

Kumpiałowska A. (red.), 2011, Skuteczne zarzadzanie ryzykiem a kontrola zarzadcza $w$ sektorze publicznym, C.H. Beck, Warszawa.

Ministerstwo Finansów, 2016, Ocena funkcjonowania kontroli zarządczej i prowadzenia audytu wewnętrznego w jednostkach samorządu terytorialnego, http://www.mf.gov.pl/c/document_library/ get_file?uuid=1680bd01-9a3f-4852-b69d-f722bfba78a5\&groupId=764034 (22.02.2018).

Rozporządzenie Ministra Finansów z 2 grudnia 2010 r. w sprawie wzoru oświadczenia o stanie kontroli zarządczej, Dz.U. 2010, nr 238, poz. 158.

Sołtyk P., 2010, Kontrola zarządcza w nowej ustawie o finansach publicznych, Wspólnota, nr 9, s. 50.

Szpor A., 2011, Kontrola zarządcza a mediacja w administracji publicznej, Kontrola Państwowa, nr 5, s. 14-15.

Ustawa z 17 grudnia 2004 o odpowiedzialności za naruszenie dyscypliny finansów publicznych, Dz.U. 2005, nr 14, poz. 114, ze zm.

Ustawa z 27 sierpnia 2009 o finansach publicznych, Dz.U. 2009, nr 157, poz. 1240 ze zm.

Winiarska K., Postuła M., 2012, Kontrola zarządcza w systemie kontroli finansów publicznych, [w:] K. Winiarska (red.), Kontrola zarządcza w jednostkach sektora finansów publicznych, Wolters Kluwer, Warszawa. 